\title{
Is Big Brother really watching us?
}

Is it worse to have supplied Iraq with materials from which poison gas can be made, or to have supplied without knowing the fate of the material? That question should now torment the British government.

MODERN governments cultivate the fancy that they are all-seeing and all-knowing, which is natural enough. If their reputations were otherwise, they would quickly find that individuals with whom they are thrust into relationships on matters as different as the payment of taxes and the regulation of prescription drugs would fail to take them seriously. But the British government, in an accident-prone patch for several weeks, has run into a nasty bout of trouble over export licences for equipment destined for Iraq.

Among other things, British companies have been substantial suppliers of chemicals that could have been (and probably were) used for the manufacture of chemical munitions. But these exports, far from being clandestine, were open and above board, duly licensed by the Department of Trade and Industry and recorded in a list of exports to Iraq supplied to the Trade and Industry Committee of the House of Commons. And that committee (which published the list in an annexe to its report), which was bent on getting to the bottom of the supply of parts for Iraq's supergun by British companies, appears to have been no more aware of the significance of what had happened than the British government itself.

The immediate and political importance of these events cannot easily be foretold. Mr Peter Lilley, the Secretary of State for Trade and Industry, has promised to give fuller details of what really happened when the British Parliament reassembles in the second half of October. Forgetfulness (or a general election) may make that ordeal unnecessary. That is why the significance of what has now emerged must be differently judged. It is both an illustration of how governments function (or can fail to function) and a measure of how much weight can be carried by arrangements to control the spread of dangerous weapons by means of agreements among potential suppliers that they will not supply.

The best-known of these is what is called the London Club agreement drawn up in September 1977 between the chief suppliers of nuclear equipment and fuel, not to supply to customers suspected of making nuclear explosives. At the time, there was great rejoicing that both the Soviet Union and France (not a signatory of the Nuclear Nonproliferation Treaty) had signed up. But it is also relevant that in the past few months, since the end of the war in the Persian Gulf, there has been strong support for a Japanese proposal for an international register of supplies of conventional arms to the world's potential troublemakers.

The legislative history of this business is not simple. The British government can require British companies and persons to apply for export licences for sensitive equipment under the Import, Export and Customs Powers (Defence) Act 1939, which goes back to the outbreak of the Second World War, and which is kept up to date by means of statutory orders (which even Members of Parliament do not have time to read).

The law obliges those wishing to export sensitive equipment to apply for a licence from the Department of Trade and Industry. To fail to appreciate that a licence may be necessary is a criminal offence; two people engaged in supplying parts for Iraq's supergun were indeed thus charged last year.

One elementary lesson from the past few days' fracas is that the British government needs modern legislation to do the job it has set itself, even if the "procedures are well understood by those in export business". As things are, those wishing to export sensitive military equipment to governments elsewhere must often be tempted not to apply for the licences legally required; the chance of being caught is small, the chance of being prosecuted successfully even if caught can be no greater.

The evidence of the list of material and equipment authorized for shipment to Iraq from Britain in the past three years can only have assured exporters that the Department of Trade and Industry was, in any case, mostly on their side. Among the bulk chemicals sent to Iraq were $£ 154,000$-worth of thiodiglycol in 1988 and $£ 33,000$-worth the following year perhaps 100 tonnes in total. It is true, of course, that thiodiglycol is a wetting agent, and is used in making sure that ink in a ball-point pen will smoothly cover the surface of the writing head. But at a milligram per pen, that would be enough to produce 100,000 million ball-point pens. Otherwise, there would be few other uses for the material except to convert it into mustard gas.

Similar conclusions will be reached about the substantial amounts of organic phosphonates and phosphonites sold to Iraq over the same period; they are convenient starting points in the manufacture of nerve gases such as Sarin (as well as, of course, of pesticides). And then there is the curious revelation that quantities of plutonium, depleted uranium and zirconium were exported.

These are so distinctively nuclear materials that $\mathrm{Mr}$ Lilley has thought it prudent to break his trappist vow - "no more details until October" - by emphasizing that only gram quantities of these materials - "far too little to make a bomb" - were ever shipped, presumably for use in medicine. But suppose, say in 1989, that Iraq had been embarked on a nuclear programme on the scale now revealed by four successive inspections of its facilities, and that it was then apparent that two or three years would have to pass before indigenous plutonium would be available. Would it not be handy, to say the least, to be able to buy a little of the eventual product on the market so as to check all those figures of cross-sections published in the text-books?

So how could such a mess have arisen? Mercifully, the memorandum now published tells all. Each year, the group of 20 people dealing with export licences of sensitive equipment from Britain have to process some 70,000 applications - say ten per person per day. From their base in the Department of Trade and Industry, they have to consult counterparts at the Foreign Office, the Ministry of Defence and less well advertized branches of the government, and well as deal with telephone enquiries pleading that without an instant licence, valuable export trade will be lost. Archlessly, the memorandum says that most of the efforts of this group have been directed at monitoring exports to the Soviet Union, eastern Europe and China. By default, Iraq seems to have enjoyed over the years a steady supply of night-vision equipment, and computer hardware and navigation equipment of unspecified function and design.

Several issues of principle arise. Jobs like these, if they are to be done well, should be done internationally, so that people are not looking over their shoulders at the balance of payments The law should be explicit and its administration transparent. And the people who do the work should be imaginative, able occasionally to put two and two together to make five. John Maddox 